\title{
PENGARUH EDUKASI VIDEO TERHADAP TINGKAT PENGETAHUAN BAHAYA TIDAK SARAPAN PAGI PADA SISWA SEKOLAH DASAR SDN GATOTSUBROTO KOTA BANDUNG
}

\author{
Mira Meliyanti \\ Program Studi Diploma Tiga Kebidanan STIKes Dharma Husada Bandung \\ mirazallea@gmail.com
}

\begin{abstract}
ABSTRAK
Sarapan pagi untuk growth dan development anak-anak,. Tapi sering jika diabaikan, hal ini dapat menimbulkan resiko bagi kesehatan dan prestasi belajar. Penelitian ini bertujuan mengetahui tingkat pengetahuan siswa sekolah dasar tentang bahaya tidak sarapan pagi sebelum dilakukan edukasi dengan video, mengetahui tingkat pengetahuan siswa sekolah dasar tentang bahaya tidak sarapan pagi setelah dilakukan edukasi dengan video. Desain penelitian adalah penelitian quasi eksperimen dengan rancangan pre test dan post test. Jumlah subjek penelitian adalah 80 siswa SDN. Data yang dikumpulkan adalah kuesioner pre test dan post test. Hasil penelitian bahwa rata-rata sebelum dilakukan edukasi video mengalami hasil yang baik yaitu $252(78.0 \%)$ dan setelah dilakukan edukasi video mengalami peningkatan yang siginifikan yaitu sebesar 307 (95.0\%).
\end{abstract}

Kata kunci: Pengetahuan Bahaya tidak Sarapan Pagi, Siswa SD

\begin{abstract}
Breakfast for children"s growth and development. But often if ignored, this can pose a risk to health and learning achievement. of knowledge of elementary school students about the dangers of not having breakfast before education with video, knowing the level of knowledge of elementary school students about the dangers of not having breakfast after education with video. The research design was a quasi-experimental study with pre-test and post-test designs. The number of research subjects was SDN students. The data collected were questionnaire pre test and post test. The results showed that on average before video education had good rsults, namely 252 (78.0\%) and after video eduvation had and significant increase of 307 (95.0\%).
\end{abstract}

Keywords: Knowledge about the dangers of not having breakfast, elementary students.

\section{PENDAHULUAN}

Sarapan merupakan suatu hal yang penting bagi pertumbuhan dan perkembangan anak, tetapi sering diabaikan, hal ini dapat beresiko pada kesehatan anak dan prestasi belajar anak.

Anak usia sekolah merupakan periode yang sangat menentukan kualitas seseorang. 
JURNAL SEHAT MASADA

Pada masa usia sekolah ini adalah suatu masa usia yang sngat berbeda dengan usia dewasa yang mana dalam masa ini didapatkan banyak permasalahan kesehatan yang sangat menentukan kualitas anak dikemudian hari. Salah satu penyebab terjadinya masalah kesehatan ini yaitu asupan makanan yang baik dan benar untuk dikonsumsi anak usia sekolah sehari-hari. ${ }^{1}$

Makanan yang sehat harus memenuhi syarat kualitas maupun kuantitas, disamping jangan mengandung zat-zat yang dapat menimbulkan penyakit. Selain memperhatikan makanan yang dikonsumsi, sebaiknya juga memperhatikan makanan yang dikonsumsi, sebaiknya juga memperhatikan frekuensi makanan dan kebiasaan makan yang baik. Menurut berbagai kajian, frekuensi makanan yang baik tiga kali dalam sehari antara lain makan pagi atau sarapan, makan siang dan juga makan malam. Akan tetapi sering kali untuk mengabaikan sarapan dengan alasan karena diburu oleh waktu. ${ }^{3}$

Pendidikan gizi disekolah mempunyai beberapa keuntungan yaitu anak mempunyai pemikiran yang terbuka dan pengetahuan yang diterima dapat dijadikan dasar bagi pembinaan kebiasaan makanannya. ${ }^{8}$ Penyuluhan gizi merupakan kegiatan yang dilakukan untuk memperkenalkan dan memberikan informasi tentang gizi yaitu pentingnya sarapan terhadap anak-anak usia sekolah. Tujuan dari penyuluhan ini diharapkan dapat meningkatkan pengetahuan anak tentang sarapan sehingga nantinya juga akan merubah sikap anak dalam membiasakan sarapan setiap hari. Adapun didalam pelaksanaan penyuluhan gizi dibutuhkan media sebagai alat bantu penyampaian informasi, sehingga media sebaiknya sesuai dengan keinginan dari penyampaian pesan. Selama ini media yang sering digunakan leflet yang hanya dapat melibatkan indra penglihatan saja. Pada penyuluhan ini, media yang akan digunakan untuk penyuluhan gizi yaitu video yang mana video lebih banyak melibatkan indra manusia.

Tujuan penelitian untuk Untuk mengetahui pengaruh edukasi video terhadap tingkat pengetahahuan bahaya tidak sarapan pagi pada siswa sekolah dasar SDN 150 Gatotsubroto Kota Bandung.

\section{METODE PENELITIAN}

Jenis penelitian yang digunakan dalam penelitian ini adalah desain penelitian quasi eksperimen dengan rancangan pre test dan post test. pendekatan waktu pengumpulan data dilakukan secara Cross Sectional yaitu suatu penelitian untuk mempelajari dinamika korelasi antara faktor - faktor resiko dengan efek, dengan cara pendekatan, atau pengumpulan data sekaligus pada suatu saat (point time approach)

Penelitian dilakukan di SDN 150 Gatotsubroto Kota Bandung pada bulan Januari sampai dengan Maret 2020. Populasi dalam penelitian ini adalah seluruh siswa kelas 4-6 berjumlah 323 orang. Sampel yang digunakan adalah total sampling, yaitu seluruh populasi diambil sebagai sampel. Teknik pengambilan sampel secara accidental 


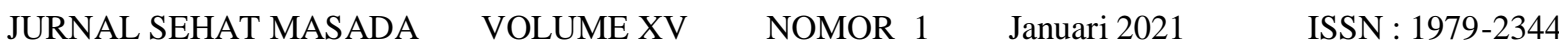

sampling yaitu pengambilan sampel secara aksidental dengan mengambil atau tersedia di suatu tempat sesuai kasus atau responden yang kebetulan ada dengan konteks penelitian

Tabel 1. Definisi Operasional

\begin{tabular}{|c|c|c|c|c|c|c|}
\hline NO & Variabel & $\begin{array}{c}\text { Sub } \\
\text { Variabel }\end{array}$ & $\begin{array}{c}\text { Definisi } \\
\text { Operasional }\end{array}$ & Alat Ukur & Hasil Ukur & $\begin{array}{l}\text { Skala } \\
\text { Ukur }\end{array}$ \\
\hline \multirow[t]{2}{*}{1.} & \multirow[t]{2}{*}{$\begin{array}{l}\text { Pengetahuan } \\
\text { siswa tentang } \\
\text { tanda bahaya } \\
\text { tidak sarapan } \\
\text { pagi }\end{array}$} & Pretest & $\begin{array}{l}\text { Segala sesuatu } \\
\text { yang belum } \\
\text { ketahui siswa } \\
\text { tentang tanda } \\
\text { bahaya } \\
\text { Tidak sarapan } \\
\text { pagi. }\end{array}$ & Kuesioner & $\begin{array}{ll}\text { 1. } & \text { Baik (Jawaban benar } \\
>75 \%) & \\
\text { 2. } & \text { Cukup (Jawaban } \\
\text { benar 50-75 \%) } \\
\text { 3. Kurang (Jawaban } \\
\text { benar <50\%). }\end{array}$ & Ordinal \\
\hline & & Posttest & $\begin{array}{l}\text { Segala sesuatu } \\
\text { yang di ketahui } \\
\text { siswa tentang } \\
\text { tanda bahaya } \\
\text { Tidak sarapan } \\
\text { pagi. }\end{array}$ & Kuesioner & $\begin{array}{ll}\text { 1. } & \text { Baik (Jawaban benar } \\
>75 \%) & \\
\text { 2. } & \text { Cukup (Jawaban } \\
\text { benar } 50-75 \%) \\
\text { 3. } \\
\text { Kurang (Jawaban } \\
\text { benar <50\%). }\end{array}$ & Ordinal \\
\hline
\end{tabular}

Alat pengumpul data yang digunakan berupa kuesioner. Kuesioner untuk siswa kelas 4-6 SDN 150 Gatotsubroto Kota Bandung yang digunakan adalah HOME (Home Observation for Measurement of the Environment ${ }^{(26)}$. Kuesioner HOME (Home Observation for Measurement of the Environment) The Early Childhood HOME inventory for 10-12 year old berisi 15 item. Kuesioner yang akan digunakan, dilakukan uji validitas berupa content validity oleh ahli keperawatan.

Pengkategorian dalam edukasi video terhadap tingkat pengetahuan bahaya tidak sarapan pagi ini menggunakan rata - rata pencapaian skor. Pengkatagorian rata - rata pencapaian skor ini menggunakan 3 variasi yaitu :

Kategori rendah, bila nilai total 0-29

Kategori sedang, bila nilai total 30-45

Kategori baik, bila nilai total 46-55

Data penelitian diperoleh dari hasil :

- Pretest, yaitu segala sesuatu yang belum ketahui siswa tentang bahaya tidak sarapan pagi.

- Posttest, yaitu segala sesuatu yang di ketahui siswa tentang bahaya tidak sarapan pagi.

Data hasil penelitian diolah dan dianalisa. Analisa yang digunakan analisa univariat dan bivariat. Analisa univariat bertujuan untuk menghitung jumlah kategori dari jawaban responden dan menghasilkan distribusi 
frekuensi dan persentasi dari tiap variabel, dengan rumus :

$$
P=\frac{n}{N} X 100 \%
$$

$\mathrm{P}=$ Presentase jumlah responden

$\mathrm{n}=$ Jumlah atau skor maksimal jawaban responden

$\mathrm{N}=$ Jumlah jawaban benar

Hasil yang diperoleh ditafsirkan

dengan menggunakan kriteria

sebagai berikut :

1 : Baik, Jika jawaban responden benar $>75 \%$

2 : Cukup, Jika jawaban responden benar 50 $75 \%$

3 : Kurang, Jika jawaban responden benar $<50 \%$

Analisa bivariat bertujuan melihat ada tidaknya hubungan antara variabel bebas dan variabel terikat yang tampak pada karangan konsep. Dalam penelitian ini dilakukan dengan memakai uji chi square dengan rumus:

$$
x^{2}=\sum \frac{(f o-f e)^{2}}{f e}
$$

Keterangan :

$\mathrm{P}=$ Presentase

$\mathrm{x}=\mathrm{Jumlah}$ jawaban benar

$\mathrm{n}$ = Jumlah atau skor maksimal

jawaban responden

\section{HASIL DAN PEMBAHASAN}

a. Hasil

Tabel 2 Distribusi Frekuensi Tingkat Pengetahuan Siswa Tentang Bahaya Tidak Sarapan Pagi Sebelum Dilakukan Edukasi Dengan Video.

\begin{tabular}{lll}
\hline \multicolumn{1}{r}{ Tingkat Pengetahuan } & f & \multicolumn{1}{c}{$\%$} \\
\hline Baik & 252 & 78.0 \\
\hline Buruk & 71 & 22.0 \\
\hline Total & $\mathbf{3 2 3}$ & $\mathbf{1 0 0}$ \\
\hline
\end{tabular}

Dari Tabel 2 diketahui bahwa rata-rata tingkat pengetahuan tentang bahaya tidak sarapan pagi sebelum dilakukan edukasi video sebagian besar responden $252(78.0 \%)$ memiliki pengetahuan yang baik

\section{Tabel 3 Distribusi frekuensi tingkat pengetahuan siswa tentang bahaya tidak sarapan pagi setelah dilakukan edukasi dengan video.}

\begin{tabular}{lll}
\hline \multicolumn{1}{c}{ Tingkat pengetahuan } & f & \multicolumn{1}{c}{$\%$} \\
\hline Baik & 307 & 95.0 \\
\hline Buruk & 16 & 5.0 \\
\hline Total & $\mathbf{3 2 3}$ & $\mathbf{1 0 0}$ \\
\hline
\end{tabular}

Dari Tabel 3 diketahui bahwa rata-rata tingkat pengetahuan tentangbahaya tidak sarapan pagi setelah dilakukan edukasi video mengalami perubahan tingkat pengetahuan menjadi sebagian besar responden 307 (95.0\%) memiliki pengetahuan yang baik.

\section{b. Pembahasan}

Berdasarkan hasil penelitian pada siswa SDN gatotsubroto diperoleh hasil bahwa tingkat pengatahuan sebelum diberi edukasi video tentang sarapan pagi memiliki hasil yang 
baik dan setelah diberikan edukasi video mengalami peningkatan yang baik. Hasil penelitian yang dilakukan secara signifikan berbeda antara pretest dan posttest $(\mathrm{p}<0,05)$.

Pemberian edukasi melalui video membuat siswa tertarik untuk memperhatikan informasi yang disampaikan terkait bahaya tidak sarapan pagi. Sehingga pengetahuan mengalami peningkatan. Video merupakan media edukasi yang menarik dan tidak membosankan bagi anak. Penelitian Hamida (2012), menemukan bahwa media yang digunakan dalam proses pembelajaran menyebabkan proses pembelajaran menjadi lebih menarik perhatian sehingga lebih mudah diimplementasikan serta sasaran tidak menjadi cepat bosan. Hal ini didukung dengan hasil penelitian Rufiati (2011), dan Zulaekah (2012) yang menemukan bahwa penggunaan media dalam mempersembahkan edukasi dapat mempengaruhi peningkatan pengetahuan.

Edukasi dengan menggunakan video ini tentunya tidak hanya terbatas pada materi tentang tidak sarapan pagi saja, akan tetapi untuk hal-hal lain dimana kebutuhan peningkatan pengetahuan diperlukan pada berbagai aspek karena selama ini permainan kata-kata mereka dihadapkan pada permasalahan-permasalahan yang mereka sendiri perlu mendapatkan bantuan. Dengan pengetahuan yang cukup diharapkan mereka dapat mengaflikasikan kedalam prilaku menghindari tidak sarapan pagi di pagi hari serta dapat mempengaruhi orang lain untuk mengenal bahaya tidak sarapan pagi.

\section{KESIMPULAN}

a. Distribusi frekuensi tentang bahaya tidak sarapan pagi sebelum diberikan edukasi video pada siswa SDN Gatotsubroto termasuk dalam kategori baik sebagian besar responden 252 (78.0\%).

b. Distribusi frekuensi tentang bahaya tidak sarapan pagi setelah diberikan edukasi video pada siswa SDN Gatotsubroto mengalami peningkatan pengetahuan yang signifikan menjadi sebagian besar responden $307 \quad(95.0 \%) \quad$ memiliki pengetahuan yang baik.

\section{DAFTAR PUSTAKA}

1. World Health Organization (WHO) tentang Angka Kematian Ibu (AKI). Tersedia: www.who.org

2. Departement Kesehatan RI 2014 tentang Kematian Ibu. Tersedia: www.depkes.go.id

3. Kemkes 2016 tentang Angka Kematian Bayi (AKB). Tersedia: www.kesga.kemkes.go.id

4. Damanik Fadilayana, Tuti, Noviardi. (2015) "Tingkat Pengetahuan Ibu Primigravida Tentang Tanda Bahaya Kehamilan Sebelum dan Sesudah Penyuluhan di Wilayah Kerja Puskesmas Rejosari”, Jom FK Volume 2

5. Angka Kematian Ibu dan Bayi di Jawa Barat 2017. www.cnnindonesia.com

6. Isdiaty Fandiar Nur, Titin Ungsianik. (2013) "Pengetahuan Tanda Bahaya Kehamilan Dan Perilaku Perawatan Kehamilan Pada Ibu Hamil Trimester III", 
7. Jurnal Keperawatan Indonesia Volume 16 hal 18-24.

8. Wenas, Ripca Aprisilia, Anita Lontaan, Berthina.H.Korah. (2014). "Pengaruh Promosi Kesehatan Tentang Tanda Bahaya Kehamilan Terhadap Pengetahuan Ibu Hamil Di Puskesmas Amurang”, Jurnal
Ilmiah Bidan Volume 2.

9. Yanti Risna Dewi, Ni Gusti Made Ayu. (2016) "Hubungan Antara Pengetahuan Ibu Hamil Tentang Tanda Bahaya dan Komplikasi Kehamilan dengan Kepatuhan Kunjungan Antenatal dan Pemilihan Tempat Bersalin di 